\title{
Corrigendum: Single-molecule studies of fork dynamics in Escherichia coli DNA replication
}

Nathan A Tanner, Samir M Hamdan, Slobodan Jergic, Karin V Loscha, Patrick M Schaeffer, Nicholas E Dixon \& Antoine M van Oijen Nat. Struct. Mol. Biol. 15, 170-176 (2008); published online 27 January 2008; corrected after print 18 June 2008

In the version of this article initially published, Karin V. Loscha was missing from the list of authors. The error has been corrected in the HTML and PDF versions of the article.

\section{Corrigendum: A mammalian microRNA cluster controls DNA} methylation and telomere recombination via Rbl2-dependent regulation of DNA methyltransferases

Roberta Benetti, Susana Gonzalo, Isabel Jaco, Purificación Muñoz, Susana Gonzalez, Stefan Schoeftner, Elizabeth Murchison, Thomas Andl, Taiping Chen, Peter Klatt, En Li, Manuel Serrano, Sarah Millar, Gregory Hannon \& Maria A Blasco

Nat. Struct. Mol. Biol. 15, 268-279 (2008); published online 2 March 2008; corrected after print 18 June 2008

In the version of this article initially published, the GEO accession number for the array data was not provided. It is GSE11229. The error has been corrected in the HTML and PDF versions of the article.

Corrigendum: Two distinct mechanisms generate endogenous siRNAs from bidirectional transcription in Drosophila melanogaster

Katsutomo Okamura, Sudha Balla, Raquel Martin, Na Liu \& Eric C Lai

Nat. Struct. Mol. Biol. 15, 581-590 (2008); published online 25 May 2008; corrected after print 18 June 2008

In the version of this article initially published, the Abstract did not convey that two conclusions regarding cis-NATs, presented in Table 1, were derived from analysis of previously published data (references 20 and 21 in the paper). The third sentence of the Abstract should read: "First, >100 cis-NATs with overlapping 3' exons generate 21-nt and, based on previously published small RNA data, Dicer-2 (Dcr-2)-dependent, 3'-end modified siRNAs." The correction has been made to the HTML and PDF versions of the article.

\section{Corrigendum: Fungal Rtt109 histone acetyltransferase is} an unexpected structural homolog of metazoan p300/CBP

Yong Tang, Marc A Holbert, Hugo Wurtele, Katrina Meeth, Walter Rocha, Marlene Gharib, Eva Jiang, Pierre Thibault, Alain Verreault, Philip A Cole \& Ronen Marmorstein

Nat. Struct. Mol. Biol. 15, 738-745 (2008); published online 22 June; corrected after print 30 July 2008

In the version of this article initially published, the author name Verreault was mistakenly spelled as Verrault. The error has been corrected in the HTML and PDF versions of the article. 